\title{
Behaviour of Brazilian export firms: implications for the Free Trade Area of the Americas
}

\author{
Renato Baumann \\ Economic Commission \\ for Latin America and the \\ Caribbean (ECLAC), Brasilia \\ Professor, University of Brasilia \\ rbaumann@cepal.org.br \\ Francisco Galrão Carneiro \\ Professor, Catholic University \\ of Brasilia \\ carneiro@pos.ucb.br \\ The analysis of integration processes between two economies \\ has traditionally focused on identifying the intensity of trade \\ creation and diversion, estimated through a simulation of \\ the impact of the reduction or elimination of trade barriers. \\ At the same time, the literature on multinational corporations \\ has stressed the growing weight of intra-firm transactions \\ in total foreign trade. This paper attempts to compare these \\ two theoretical approaches by analysing the geographical \\ orientation of the leading Brazilian export firms and, on that \\ basis, inferring the potential impact on estimates of the \\ effects of the Free Trade Area of the Americas (FTAA). The \\ hypothesis is that, by taking into account the significance \\ of subsidiary firms in the country's foreign trade and the \\ geographical concentration of these firms' external \\ commercial transactions, the results derived from the creation \\ of FTAA may differ from those obtained through simulations \\ based on the reduction or elimination of trade barriers.
}




\section{Introduction}

Since the publication of Viner's study (1950), the analysis of the effects of integration processes between two economies has traditionally focused on identifying the impact of the reduction or elimination of trade barriers on the participating countries' trade balance and production structure.

The two basic concepts proposed by Viner -trade creation (emergence of new activities in the trade between the participating countries) and trade diversion (reduction of imports of products offered by third countries)- are still the main topic of most analyses. Thus, an integration process could be said to be beneficial from an economic standpoint if the former effect exceeded the latter within an acceptable time frame.

Ex ante appraisals of the consequences of an integration exercise have therefore tended to identify these two effects primarily on the basis of a simulation of the results derived from the reduction or elimination of trade barriers between the participating countries.

This type of approach is based on certain assumptions, one of them being that international trade takes place among different firms in different countries. Each article is produced by a production unit in a given country. The profits obtained are added to the national income of the home country of each firm, and thus each country supports its most competitive units as against the most competitive units in the other countries (Markusen and Venables, 1995).

The literature on multinational firms, however, points out some aspects of the relations between the parent company and its subsidiaries which shed some new light with respect to the correctness and validity of this assumption. This has given rise to a whole new

The views expressed here are the sole responsibility of the authors and do not necessarily represent the positions of the institutions mentioned in this article. The authors wish to express their gratitude to the Secretariat of Foreign Trade (SECEX), for the access provided to its database on export firms, and to Rogerio Boueri Miranda, Leandro Magalhaes and Paulo Roberto da Silva Jr. for their assistance in data processing. branch of international trade theory dealing with intrafirm transactions. Nonetheless, the relationship of these transactions to studies on the integration process has been insufficiently explored.

This paper attempts to integrate these two theoretical approaches, first by analysing the geographical orientation of the leading Brazilian export firms and then by deducing the potential effects of the creation of a free trade area in the hemisphere. It is held that, since capital-exporting firms are subject to a trade interaction with their parent company, an argument can be made for re-evaluating the results of exercises aimed at estimating the amount of trade creation and diversion that would be associated with the Free Trade Area of the Americas (FTAA).

The basic purpose of the paper is to verify whether foreign-owned firms that trade with the rest of the world tend to concentrate more of their exports and imports on the country of origin of their capital than on other countries. If this hypothesis can be confirmed, there is reason to assume that estimates of trade creation and diversion made on the basis of the sectoral distribution of trade barriers should be judged in terms of the role played by the economic agents acting in each sector. The concern behind this analysis is based on the negotiation process aimed at establishing FTAA; nonetheless, since this case deals with the leading Brazilian export firms, the analysis is also useful for making a general assessment of simulation exercises used to estimate trade creation and diversion.

The methodology of the analysis is based on the calculation of probabilistic econometric models to verify the determining factors in the exports of leading Brazilian firms in the period 1995-2000. The econometric model estimates the probability that a given firm will export to the country of origin of its capital or to a given trade bloc.

The paper is divided into five sections. Section II, following this Introduction, establishes the reasoning behind the argument; section III describes how the primary data were compiled and section IV examines the results. Lastly, section $\mathrm{V}$ presents some conclusions.

BEHAVIOUR OF BRAZILIAN EXPORT FIRMS: IMPLICATIONS FOR THE FREE TRADE AREA

OF THE AMERICAS - RENATO BAUMANN AND FRANCISCO GALRÃo CARNEIRO 


\section{II}

\section{Theoretical basis}

For some time now, the theoretical explanation of international trade flows as being based on the availability of production factors in the various countries has proved to be insufficient. Since the mid1950s, the recognition that most international trade in goods consists of trade in industrial products and is carried out between developed countries has given rise to alternative attempts to explain the trade in this type of product. Formulations based on a "product cycle" (Vernon, 1966) and the technological gap between countries (Posner, 1961) are two of the most telling examples.

Recently, a theoretical approach combining industrial organization with trade theory -the so-called "new trade theory"- represented a methodological advance (Helpman and Krugman, 1985; Krugman, 1986). This approach offered the possibility of explaining the results associated, for example, with multinational corporations and trade relations between the parent company and its subsidiaries, by taking into account elements such as economies of scale and product differentiation.

By incorporating these elements -economies of scale, imperfect competition and product differentiationthe analysis reveals, for example, that there is a form of specialization in the trade in goods that does not depend on the relative supply of production factors, and that complementary production processes may emerge among factories located in different countries, leading to an intensification of intra-firm transactions rather than the results that would be expected based on traditional theory. The basic argument assumes that, for certain types of products, international vertical integration of the production process may be a precondition for achieving production efficiency.

This type of situation requires an identification of the attributes that make intra-firm transactions more profitable than those with other firms. The arguments are frequently related to the need for highly trained workers in the production process, or to the assumption that the sale of products to external consumers requires something more than industrial processing, since it also involves technical support services.

Similar results can be seen, for example, from an analysis of the effects of barriers to the international flow of skilled labour, or the existence of differences in legislation concerning patents, licences and other operational aspects of major firms. ${ }^{1}$

The key factor is that the existence of such barriers or constraints in the production or marketing process raises a firm's costs. The firm must therefore exert control, in another country nearer to consumers, over activities that are divorced from the production process as such. It must face this type of service cost in both the country of origin and the other country if it wants to operate in both markets. Accordingly, a large firm finds it cheaper and more efficient to manage these steps internally, especially in the case of activities specific to it. $^{2}$ More internal transactions will therefore result, even among units located in different countries.

Note that this type of procedure is not universal, since it applies only (or with greater intensity) to some types of products. In general, these are products or services that involve a greater demand for highly skilled workers. For example, a recent study by the Organization for Economic Cooperation and Development (OECD) indicates that the percentage of intra-firm transactions (more than $50 \%$ of the firm's total international transactions) tends to be high in the pharmaceutical, computer, semiconductor and motor vehicle industries. The same study shows percentages of less than $10 \%$ for the iron and steel and wearing apparel industries ${ }^{3}$ (OECD, 1996).

The conclusion -and this confirms the above reasoning-is that firms making intensive use of scientific know-how and mass production depend to a greater extent on high-technology and quality inputs, a well-trained workforce and the availability of highly specialized parts and components. Firms place a considerable strategic value on acquiring these inputs, so they prefer to maintain direct control over their availability, through direct investment and intra-firm transactions.

\footnotetext{
${ }^{1}$ Examples of models of this type are given in Markusen and Maskus (1999) and Baldwin (1989).

${ }^{2}$ For instance, in the case of firms having a monopoly on the patent for the commodity or its components and on the final product (pharmaceuticals, computer technology products).

3 These findings are similar to those of Bonturi and Fukasaku (1993). A like phenomenon was found in the trade relations between Japanese firms and their subsidiaries in Takeuchi (1990).
} 
III

\section{Methodology}

\section{Data}

In practice, data are systematically available on intrafirm transactions only in the United States -thanks to the publication, by the Department of Commerce, of trade statistics for United States firms with their subsidiaries- and in Japan. Intra-firm transactions are estimated in the range of $30 \%$ to $40 \%$ of total United States external trade.

In Brazil, only the Foreign Capital Census, conducted by the Central Bank in 1995, could provide any estimate of the volume of these types of transactions (around 20\%), although it does not disaggregate the data by sector. 4

A recent study conducted by the Federal Internal Revenue Secretariat (2002), based on a sampling of the six largest export firms and seven largest import firms in the country, partly confirms the sectoral concentration of intra-firm transactions: among exporters, the percentages are higher in the manufacture and assembly of motor vehicles and in wholesale commerce, and among importers, in the manufacture of chemicals and machinery and equipment.

In Brazil's case, the lack of detailed data by sector or firm made it quite difficult to do research on intrafirm trade. An alternative methodology was used by Baumann (1995), and the same approach is taken here. Owing to the lack of specific data, we shall assume that there is a close link between the ownership of a firm's capital and its marketing channels in the country of origin of the capital. Thus, for a firm whose capital is preponderantly from country $\mathrm{A}$, trade transactions with that country will essentially be with the parent company and with the marketing channels which this parent company uses in A, and transactions with third countries, if any, will be very limited. This is not the same concept as intra-firm trade, of course, but it is the best empirical approximation on the basis of the available data.

\footnotetext{
4 The Central Bank's second Foreign Capital Census, in 2000, gave a figure of US\$ 21 billion for these transactions, representing 38\% of total exports. For imports, the figure rose from US\$ 8.5 billion to US\$ 18.2 billion in the same period, representing $17 \%$ and $33 \%$, respectively, of the value of imports in 1995 and 2000.
}

Special tabulations were provided by the Secretariat of Foreign Trade (SECEX), with data on the 1,000 largest export firms in Brazil for the period 1995 to 2000. Each firm was identified by its listing in the National Register of Legal Persons (CNPJ), so that firms in the same group under a different listing are considered separately.

Since the important factor in the analysis was the ownership of the firms' capital, the owners were identified on the basis of the data provided on company web sites and in specialized publications ${ }^{5}$ concerning the country of origin of each firm's capital.

The available information shows the ownership of capital, the values of exports in 2000 disaggregated by product and country of destination, exports and market of destination by firms and products in 1995, and imports (by country of origin of imports of each product) for the 1,000 largest exporters in $2000 .^{6}$ These firms represented nearly $84 \%$ of total Brazilian exports in that period.

The data were assembled on the basis of this information. The values of exports in 1995 were obtained for 459 firms, and the values of imports in 2000 for 192 firms. The sector of activity of each firm was defined using the Table of Codes and Descriptions of the National Classification of Economic Activities (CNAE). This made it possible to define the area of activity of 768 of the 1,000 firms.

Data on the firms' net worth (1995-2000) and net earnings (for the same years) were taken from the annual edition of Mil maiores empresas brasileiras, published by the Gazeta Mercantil. For net earnings in 1995, information was obtained on 356 firms, and for the year 2000, on 435 firms. With respect to net worth, information was obtained on 318 firms for 1995 and 404 for 2000.

The biggest problem in identifying the values of net earnings and worth is that the above-mentioned

\footnotetext{
${ }^{5}$ Including Guia Interinvest and Mil maiores empresas brasileiras, published by the Gazeta Mercantil. The basic criterion was to classify as foreign those firms whose foreign-controlled capital represented at least $25 \%$ of their capital or the majority of their voting capital.

${ }^{6}$ Exports and imports in value terms.
} 
publication combines several firms with different listings in the National Register of Legal Persons (CNPJ) into a single holding company, whereas the SECEX data are disaggregated by production units. The solution in these cases was to divide up the totals of net earnings and worth among the different companies in the same group.

\section{Statistics}

Table 1 summarizes the basic data for each variable.

Figures 1 and 2 show the distribution of exports and imports of the 1,000 largest exporters, by country of origin of the controlling capital.

Although the majority of exports in the sample were from national firms, companies whose capital comes from the United States, Germany and Italy represent a significant part of this group. Similarly, a strong concentration of import value can be seen: $54 \%$ of the value was accounted for by national firms and a further $24 \%$ by United States and German companies.

Table 2 shows the number of firms by country of origin of their controlling capital. Among foreign

TABLE 1

\section{Brazil: Total data by variable}

\begin{tabular}{lc}
\hline Variable & Number of data \\
\hline Exports in 2000 & 1000 \\
Exports in 1995 & 459 \\
Imports in 2000 & 291 \\
Net earnings in 2000 & 435 \\
Net earnings in 1995 & 356 \\
Net worth in 2000 & 318 \\
Net equity in 1995 & 404 \\
Economic sectors & 768 \\
Firms with all data & 55
\end{tabular}

Source: Prepared by the authors, on the basis of primary data from the Secretariat of Foreign Trade (SECEX).

TABLE 2

\section{Number of firms by country}

\begin{tabular}{lc}
\hline Country & Number of firms \\
\hline Brazil & 660 \\
United States & 82 \\
Germany & 43 \\
France & 22 \\
Japan & 19 \\
Switzerland & 18 \\
Italy & 15 \\
Bermuda & 15 \\
United Kingdom & 12 \\
Canada & 2 \\
\hline
\end{tabular}

Source: Prepared by the authors, on the basis of primary data from SECEX. companies, there is a notable concentration, in the group formed by the largest exporters, of firms whose capital originates in the United States, Germany and France (two thirds of the 228 foreign firms). ${ }^{7}$

Taking exports by sector, a reasonable concentration exists: the four main economic activities

FIGURE 1

Brazil: the 1,000 largest export firms in 2000. Distribution of exports by country of origin of capital

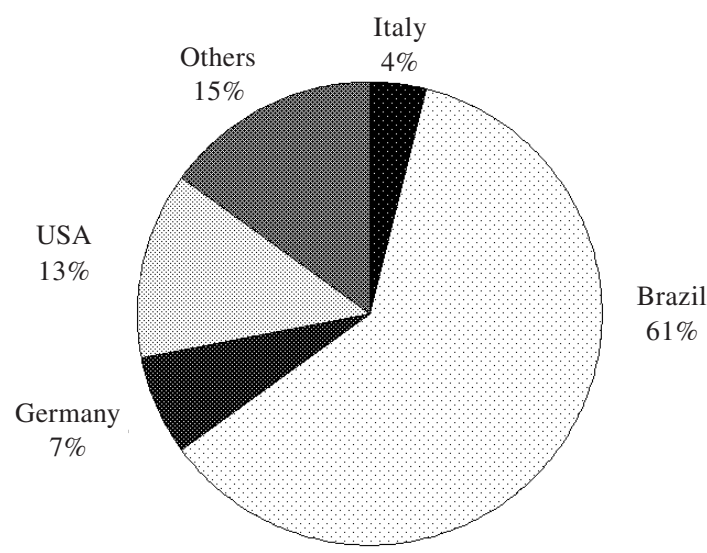

Source: Prepared by the authors, on the basis of primary data from SECEX.

FIGURE 2

Brazil: the 1,000 largest export firms in 2000. Distribution of imports by country of origin of capital

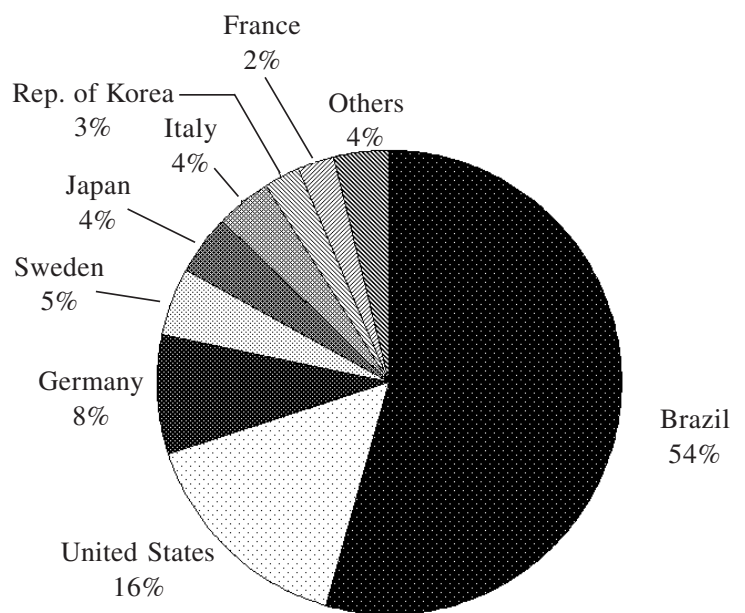

Source: Prepared by the authors, on the basis of primary data from SECEX.

${ }^{7}$ It was not possible to obtain more data on firms controlled by registered capital of Bermudan origin. 
-food and beverages, metallurgy, motor vehicles and metallic minerals- represent over half of sales abroad, and the 12 main sectors account for more than $90 \%$ of the total exported in the sample (figure 3). As for imports, two thirds of the sample represented firms operating in the sectors of motor vehicles and parts, chemicals and petrochemicals, domestic appliances and metallurgy (figure 4).

\section{Description of models}

Our objective is to describe an econometric model to: (i) measure the effects on a firm's exports of various factors, including the origin of its capital, the size of the firm and the geographical concentration of its exports and imports; and (ii) determine the likelihood that a firm will export primarily to the countries of origin of its capital, and the probability that a firm will import from its parent company's home country.

First, we shall deal with the factors determining the total exports of the firms in our sample. The estimated model was described by the following equation:

$$
\text { Export }_{i}=\beta_{0}+\beta_{1} \mathrm{X}_{i}+\gamma Z_{i}+e_{i}
$$

where Export is an export operation entered in the data bank, $\mathrm{X}$ is a binary variable indicating whether the exports are channelled to a given trade bloc (FTAA, MERCOSUR or NAFTA, for example), and Z is a vector containing other important variables for determining total exports such as:

i) Growth rate of exports by firm from 1995 to 2000;

ii) The firm's foreign participation rate, defined as the sum of its imports and exports divided by its income in 2000;

iii) Ratio of the firm's imports to its net income in 2000;

iv) Growth rate of net income by firm from 1995 to 2000; and

v) Use of dummy variables (for the United States, Canada, Western European countries, Asian countries and other Latin American countries) to identify potential differences in firms' behaviour depending on the country of origin of their capital.

Variable $X$ was built on an algorithm identifying the optimal cut-off line for each bloc to which exports are sent (FTAA, MERCOSUR, NAFTA). Thus, the cut-off lines of the dummy variables destsur, destalca and desttlc were chosen by applying a SAS routine, which

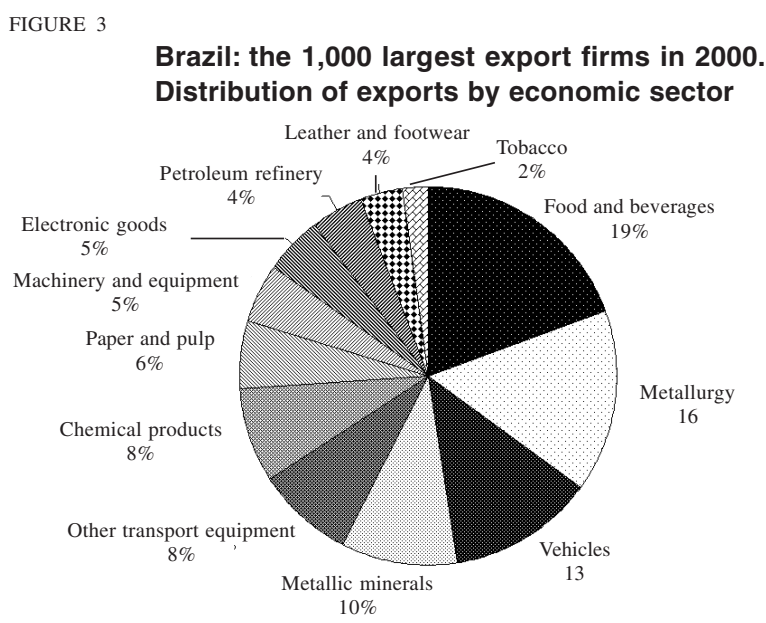

Source: Prepared by the authors, on the basis of primary data from SECEX.

FIGURE 4

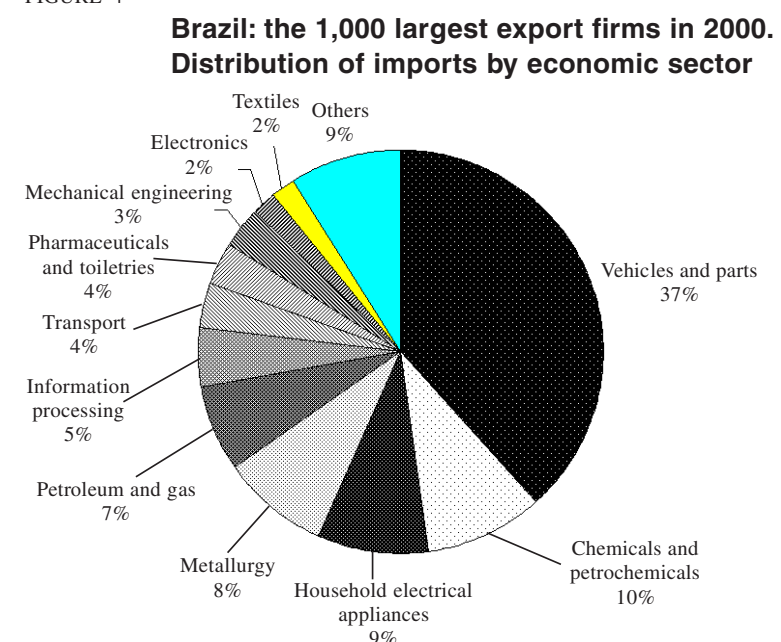

Source: Prepared by the authors, on the basis of primary data from SECEX.

selected the optimal values for each of the variables through a sequential search, by which the complete equation was estimated (that is, with all the variables of the model and the three dummy variables) and the coefficients of determination of each regression were obtained. In practice, the programme varied each of the cut-off lines from $1 \%$ to $100 \%$ by $1 \%$ intervals, and combined all the possibilities of cut-off lines. On this basis, the regressions were calculated (a total of one million) with the variables produced by all the combinations, selecting from among them the regression with the highest $\mathrm{R}^{2}$.

The coefficients $\beta_{0} \beta_{1}$ and $\gamma$ represent the sensitivity of exports to each factor, in order to calculate the relative weight of the marketing channels. 
The final description of the above equation [1] takes the following form:

$$
\begin{gathered}
\text { expinc }=\beta_{0}+\beta_{1} \text { comext }+\beta_{2} \text { impsal }+\beta_{3} \\
\text { salinc }+\beta_{4} \text { destsur }+\beta_{5} \text { destalca }+\beta_{6} \text { desttlc }+\beta_{7}
\end{gathered}
$$

where:

expinc $\rightarrow$ growth rate of exports by firm from 1995 to 2000

comext $\rightarrow$ rate of firm's foreign participation (firm's imports in 2000, plus firm's exports in 2000 divided by firm's income the same year)

impsal $\rightarrow$ ratio of firm's imports in 2000 to its net earnings that year

salinc $\rightarrow$ growth rate of firm's net income from 1995 to 2000

destsur $\rightarrow$ dummy variable representing whether more than $25 \%$ of the firm's exports in 2000 were channelled to countries of the Southern Common Market (MERCOSUR) ${ }^{8}$

destalca $\rightarrow$ dummy variable representing whether more than $48 \%$ of the firm's exports in 2000 were channelled to countries of the Free Trade Area of the Americas (FTAA)

desttlc $\rightarrow$ dummy variable representing whether more than 54\% of the firm's exports in 2000 were channelled to countries of the North American Free Trade Agreement (NAFTA).

\section{Analysis of effect of geographical concentration}

After verifying the determining factors in the growth rates of exports, we explored the significance of the relationship to the country of origin of the capital in estimating the potential effects on the growth of Brazil's exports and imports if it joins FTAA.

The analysis was made by applying a probabilistic (Probit) model, which considers the possibility of exporting to a given region or country as a function of explanatory variables. For this exercise we selected the following variables: (i) origin of the firm's capital; (ii) relative weight of exports to the country providing the firm's capital in its total exports; (iii) relative weight of imports from the country providing the firm's capital in its total imports; (iv) value of the firm's total exports

\footnotetext{
${ }^{8}$ Cut-off levels for regional blocs were determined by using the same procedure as described above.
}

and imports; (v) use of dummy variables (for the United States, Canada, Western European countries, Asian countries and other Latin American countries) to identify the potential differences in firms' behaviour depending on the countries of origin of their capital; (vi) weight of exports to FTAA, MERCOSUR and other groups of countries in proportion to the firm's total exports; and (vii) weight of imports from FTAA, MERCOSUR and other groups of countries in proportion to the firm's total exports.

The estimated equation presents the following general form:

$$
\operatorname{Pr}(\text { Destination }=1 \mid X)=C D F\left(\beta_{0}+X_{i}+\gamma Z_{i}+e_{i}\right)
$$

where the variable Destination has the value 1 if the firm exports more than a certain percentage of its total exports to a given country or region, and 0 otherwise, while $C D F$ is the cumulative distribution function. The groups of countries/regions used to define the dependent variable Destination were those of direct commercial interest to Brazil, such as MERCOSUR, FTAA, the United States and Canada, and NAFTA as a whole.

The Probit model describes the behaviour of a dummy variable in terms of a linear regression on nonrandom explanatory variables contained in vector line $X_{t}^{\prime}$ :

$$
Y_{t}=X^{\prime}{ }_{t} \beta+\mu_{t}
$$

The term $X^{\prime}{ }_{t} \beta$ represents the characteristics of firm $t$ which encourage this firm to export to a given country or region. A mechanical interpretation would be that $X_{t}{ }_{t} \beta$ represents the probability that firm $t$ will export to the region in question.

Since $Y_{t}$ may only have the values 0 or 1 , the residuals $\mu_{t}$ may only have the values $-X^{\prime}{ }_{t} \beta$ or $1-X^{\prime}{ }_{t} \beta$. This being the case, the residuals are not continuous and therefore are not distributed normally. Thus the probability that $\mu=1-X^{\prime}{ }_{t} \beta$ is equal to the probability that $Y=1$, which is equivalent to $X^{\prime}{ }_{t} \beta$.

It is therefore necessary to use a generalized least squares (GLS) procedure, which consists of estimating the values of $\beta$ via ordinary least squares (OLS) and then applying its estimated values to weight the observations and obtain efficient estimates.

In the specific case of a Probit model, we used a normal CDF, that is, if a variable $\mathrm{Z}$ has a normal distribution with a mean $\mu$ and variance $\sigma^{2}$, its probability density function (PDF) will be given by:

BEHAVIOUR OF BRAZILIAN EXPORT FIRMS: IMPLICATIONS FOR THE FREE TRADE AREA

OF THE AMERICAS - RENATO BAUMANN AND FRANCISCO GALRÃO CARNEIRO 


$$
f(Z)=\frac{1}{\sqrt{2 \pi \sigma}} e^{\frac{-\left(Z-\mu_{Z}\right)^{2}}{2 \sigma^{2}}}
$$

and its CDF by:

$$
\mathrm{F}(\mathrm{Z})=\int_{-\infty}^{Z_{0}} \frac{1}{\sqrt{2 \pi \sigma}} \frac{-\left(\mathrm{Z}-\mu_{\mathrm{Z}}\right)^{2}}{e^{2 \sigma^{2}}}
$$

To establish the cut-off line relative to the amount exported to a given destination, which would characterize the presence of the attribute "exporter" (or value 1 for the variable Destination), we used an algorithm constructed in the following manner. For each firm, we calculated the percentage of exports channelled to a given geographical/economic region (for instance, FTAA, MERCOSUR, country of origin of the capital or another country). Associated with it, a new dichotomous variable was generated which had the value $l$ if that percentage exceeded $x \%$, and the value 0 otherwise. A routine was then developed which varied this minimal value from $1 \%$ to $99 \%$, with $1 \%$ increments. For each new value of the cut-off line $x$, values were obtained for the dichotomous variable which served as an endogenous variable in the Probit model. For each batch, the probability index was calculated, and it functioned as a parameter for adjusting the model to the data. At the end of this process, the cut-off with the highest probability index was chosen.

\section{IV}

\section{Empirical analysis}

The estimated results for equation [1] appear in table 3 and suggest that firms which had a high level of participation in foreign trade and which registered some growth in sales from 1995 to 2000 also increased their exports. This growth seems to have occurred primarily in firms with export channels to the MERCOSUR, NAFTA and FTAA countries, as suggested by the positive coefficients of the variables which indicate the preferential destination of exports from those firms (destsur, destalca and desttlc).

The estimated model seems statistically sound, with a coefficient of determination adjusted for the number of degrees of freedom of nearly $37 \%$, a DurbinWatson statistic of 1.895 (which suggests there is no evidence of anomalies in the residues and functional form), and all the explanatory variables having coefficients which differ statistically from 0 .

The sample used for this estimate contained only 43 firms of a total of 182 included in the data bank. ${ }^{9}$ This smaller number of firms was due mainly to the lack of data on some firms' imports from 1995 to 2000. Since we were working with growth rates, lack of information on any of the variables for a firm in only

\footnotetext{
${ }^{9}$ The sample of 182 firms corresponds to firms which had all the data with respect to the export variables by country of destination, net earnings and net worth between 1995 and 2000. The number drops to 43 because 139 of them were domestically controlled and therefore excluded from the sample.
}

one of these years entailed the exclusion of that firm from the sample. Thus, the results must be interpreted with all due caution, since they are based on a small sample.

The coefficient of the variable comext indicates that an increment of one percentage point in a given firm's share in foreign trade leads to an increase of nearly 2.14 percentage points in its exports. That result is corroborated by the coefficient of the variable salinc, which represents the increase observed in sales from 1995 to 2000. Its positive coefficient denotes that an increment of one percentage point in sales results in an increase of about 0.38 percentage points in the firm's total exports.

It is worth noting, in table 3 , that if the ratio of a firm's imports to its net earnings increases, the growth rate of its exports drops, as is reflected in the negative coefficient of the variable impsal. In other words, for an increment of one percentage point in the ratio of imports to net earnings, there is a reduction in the growth rate of exports of nearly 1.70 percentage points. The negative coefficient for impsal, however, does not necessarily imply the non-existence of a virtuous circle between imports and exports; this may simply be due to the fact that firms which already have high levels of foreign trade also face greater difficulty in expanding their share of that trade. In order to confirm the existence of this virtuous circle, it would be necessary to have data on imports in 1995. 
TABLE 3

Brazil: determinants of growth rate of exports, $1995-2000^{a}$

\begin{tabular}{|c|c|}
\hline Explanatory variables & Estimated coefficients \\
\hline Constant & $\begin{array}{l}-4.5524 \\
(1.424)\end{array}$ \\
\hline Comext $^{\text {b }}$ & $\begin{array}{c}2.1353 \\
(0.503)\end{array}$ \\
\hline Impsal $^{\mathrm{c}}$ & $\begin{array}{l}-1.6904 \\
(0.397)\end{array}$ \\
\hline Salinc ${ }^{\mathrm{d}}$ & $\begin{array}{c}0.3834 \\
(0.148)\end{array}$ \\
\hline Destsur ${ }^{\mathrm{e}}$ & $\begin{array}{c}0.7629 \\
(0.495)\end{array}$ \\
\hline Destalca $^{\mathrm{f}}$ & $\begin{array}{c}0.2447 \\
(0.549)\end{array}$ \\
\hline Desttlc $^{\mathrm{g}}$ & $\begin{array}{c}1.1451 \\
(0.484)\end{array}$ \\
\hline $\mathrm{N}$ & 43 \\
\hline $\mathrm{R}^{2}$ & 0.4599 \\
\hline $\mathrm{R}^{2}$ adjusted & 0.3699 \\
\hline Durbin-Watson statistic & 1.8950 \\
\hline
\end{tabular}

Source: Prepared by the authors, on the basis of primary data from SECEX.

a The number in brackets are the standard errors of each coefficient.

${ }^{\mathrm{b}}$ Foreign participation rate.

${ }^{c}$ Ratio of imports to net earnings.

${ }^{\mathrm{d}}$ Growth rate of net income.

e Dummy variable representing whether more than $25 \%$ of exports went to MERCOSUR countries.

${ }^{f}$ Dummy variable representing whether more than $48 \%$ of exports went to FTAA countries.

g Dummy variable representing whether more than $54 \%$ of exports went to NAFTA countries.

As for the relationship between the ownership of capital and the destination of exports, our estimates reveal some interesting results. For example, firms which export preferentially to MERCOSUR, NAFTA or FTAA would tend to benefit from the greater volume of trade generated between 1995 and 2000, in comparison to those which showed a preference for other markets.

This affirmation is confirmed by the positive and statistically significant coefficients of the dummy variables destsur, destalca and desttlc, which represent the impact of the destination of a given firm's exports on the rate of increase in its total exports. In fact, it may be said that firms which sent more than $25 \%$ of their total exports to MERCOSUR in 2000 showed a rate of increase in sales abroad about 0.76 percentage points higher than that registered by firms which exported less than this amount to MERCOSUR.
Similarly, firms which traded more than $45 \%$ of their exports with FTAA countries recorded a rate of export growth nearly 0.25 percentage points higher than that of firms which exported less than this amount to the same destination.

Lastly, the estimates indicate that firms exporting more than $54 \%$ to the NAFTA countries gained an advantage in terms of an increase in their foreign trade of 1.15 percentage points compared to the rest, which reflects the great vitality of the NAFTA market in the period in question.

\section{The case of United States and Canadian firms}

The United States and Canadian firms in the sample exported a total of US\$ 6.3 billion in 2000 in comparison to US\$2.9 billion in 1995, representing a growth of $114.2 \%$ for these firms' exports in the period, much higher than the $20.7 \%$ for total exports in the sample (from US\$ 38.3 billion to US\$ 46.3 billion).

It is interesting to note that, in these firms' total exports, the share of those exported to the United States and Canada decreased. In 1995, they exported 27.6\% to the United States and Canada, whereas by 2000 this proportion had dropped to $20.7 \%$.

Figure 5 shows the other main countries of destination of exports of firms financed by United States and Canadian capital, while figure 6 presents the sectoral share of these exports. Figure 7 illustrates the geographical distribution of the countries of origin of the imports in the sample.

FIGURE 5

Brazil: Leading Canadian and United States export firms in 2000: destination of exports in percentages by country

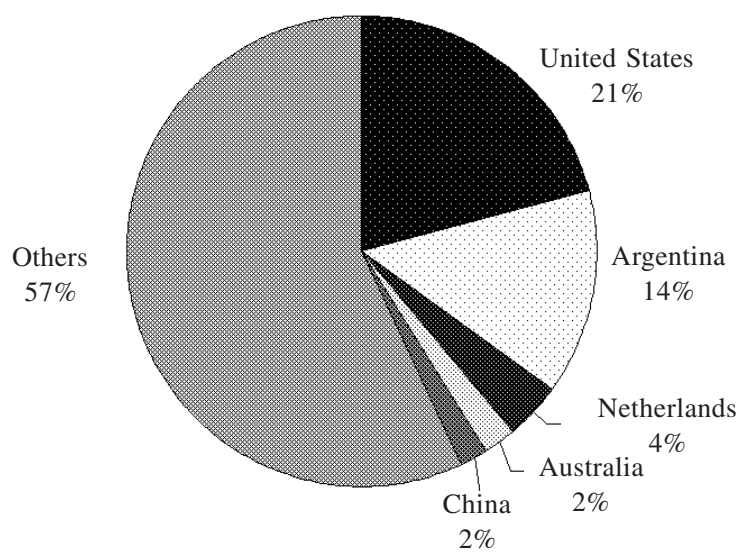

Source: Prepared by the authors, on the basis of primary data from SECEX. 
As seen in figure 5, a reasonable geographical dispersion of exports from these firms occurred in 2000; the group of "other countries" absorbed $57 \%$ of the export value. The impact of MERCOSUR is worth noting, since Argentina was the market of destination for $14 \%$ of exports.

In sectoral terms, as illustrated in figure $6,40 \%$ of these firms' total exports corresponded to the motor vehicles and parts, metallurgy and machinery and equipment sectors.

Looking at the geographical origin of imports (see figure 7), we continue to see the group of "other countries" as the primary source, accounting for $56 \%$ (similar to the share of exports), but the relative weight of the United States is double that of exports. This result shows the importance of analysing the potential impact of FTAA: subsidiaries of United States and Canadian companies operating in Brazil present a reasonably diversified geographical structure for their exports, but they depend on the United States for nearly $40 \%$ of their imports.

In terms of sectors, two thirds of the imports by these subsidiaries represent firms in the motor vehicles and parts, chemicals and petrochemicals, domestic appliances and metallurgy sectors. ${ }^{10}$

Imports by these firms in 2000 account for a total of US\$ 3.6 billion, of which $38.3 \%$ come from their countries of origin. It is noteworthy that although the proportion of imports was larger than that of exports in 2000 (37.5\% compared to $20.7 \%$ ), these firms' trade with their countries of origin produced a surplus of US\$ 2.8 billion.

On the basis of the data on exports and imports by United States and Canadian firms operating in Brazil, we estimated a Probit model, described by the following equation:

$$
P(\text { desth }>\text {.20 })=\phi(\text { comext }, \text { expsal, expinc })
$$

where desth is the probability of channelling more than $20 \%$ of exports to the United States or Canada, ${ }^{11}$ comext is the ratio of foreign trade (exports plus imports) to the firms' net income, expsal is the rate of growth of the firm's net earnings from 1995 to 2000 and expinc

\footnotetext{
${ }^{10}$ Note that there is a certain similarity with sectors in which the above-mentioned OECD study observed the existence of more intense intra-firm transactions.

${ }^{11}$ The cut-off line of $20 \%$ was defined on the basis of the algorithm described in the previous section.
}

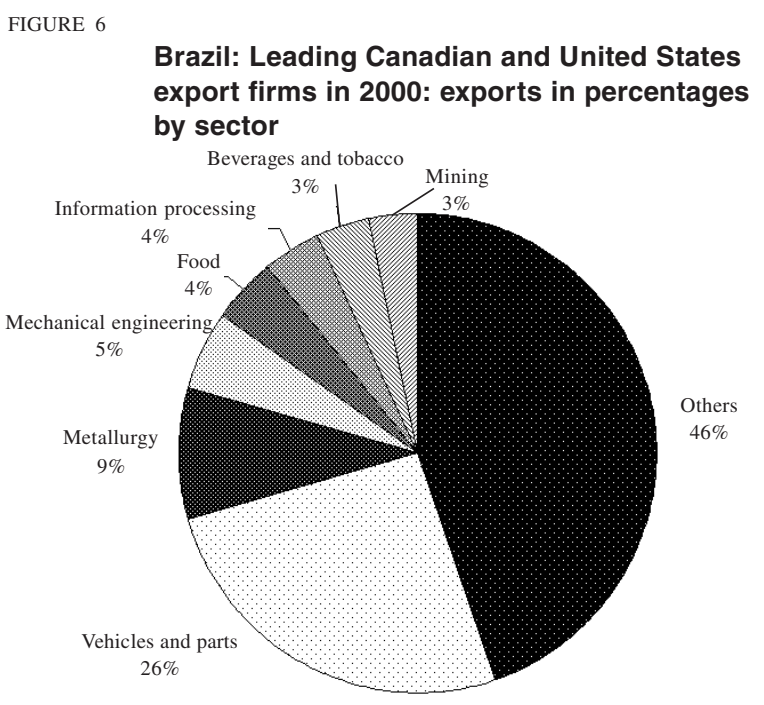

Source: Prepared by the authors, on the basis of primary data from SECEX.

FIGURE 7

Brazil: Leading Canadian and United States importers in 2000: imports by country

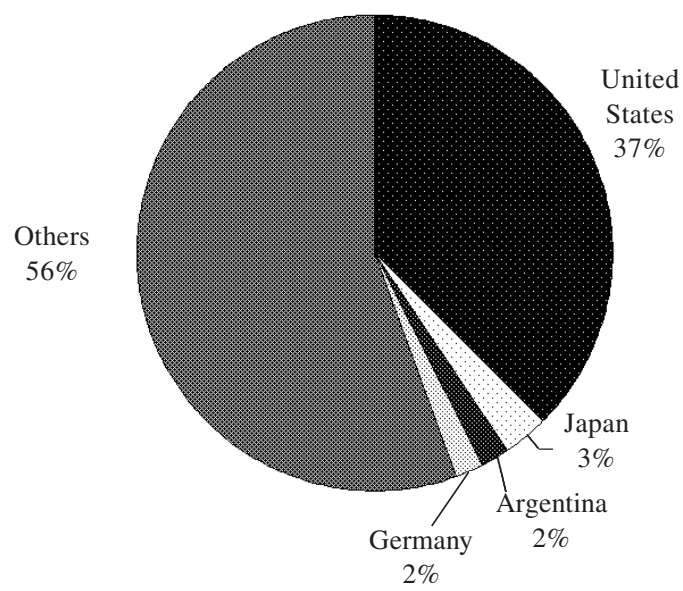

Source: Prepared by the authors, on the basis of primary data from SECEX.

is the rate of growth of exports from 1995 to 2000. The results are described in table 4.

Out of 56 observations, the probability coefficient was 17.18 , and therefore significant at a level of $10 \%$.

The positive values of all the variables mean that there is a greater probability that any of the firms in question will export more than $20 \%$ of its foreign sales to the United States or Canada (i) the greater the ratio 
TABLE 4

Probit model for exports to the United States and Canada

\begin{tabular}{lcc}
\hline Variable & Coefficient & Standard error \\
\hline Intercepto $^{\mathrm{a}}$ & 1.11714 & 0.585220 \\
Comext $^{\mathrm{b}}$ & 0.00831 & 0.004718 \\
Expsal $^{\mathrm{c}}$ & 0.00619 & 0.003114 \\
Expinc $^{\mathrm{d}}$ & 0.25599 & 0.109750 \\
\hline
\end{tabular}

Source: Prepared by the authors, on the basis of primary data from SECEX.

a Intercept.

${ }^{b}$ Foreign trade as a proportion of net income.

${ }^{c}$ Growth rate of net earnings.

${ }^{\mathrm{d}}$ Growth rate of exports.

of its foreign trade to its net income, (ii) the greater the growth of its net income and (iii) the greater the share of sales to the United States and Canada in its exports.

This confirms the direct relationship between the degree of participation in the North American market and the option to continue taking part in it. In other words, it is an indication that the subsidiaries operating in Brazil tend to participate in the market of origin of their parent firms.

\section{Analysis by regional blocs}

Four analogous experiments were conducted, applying the same Probit model as described above to different trade blocs. In each model, the dependent variable was constructed on the basis of the proportion of each firm's exports to a given destination. If this proportion exceeded a given cut-off point, the variable had a value of 1 , and otherwise 0 . The cut-off lines were obtained via the algorithm described above, which seeks to maximize the probability coefficient of the estimated equations for all possible cut-offs.

Table 5 shows the destinations stipulated in each model and the cut-off line obtained.

These four models applied the same exogenous variables. The variable expsal represents the ratio of total exports in 2000 to the firm's net income the same year. Expat represents total exports in 2000 as a proportion of the firm's net worth that year; expinc is the growth rate of exports by firm from 1995 to 2000; salinc is the growth rate of net earnings by firm from 1995 to 2000; and patinc is the growth rate of net worth by firm from 1995 to 2000 .

The estimated results are shown in table 6. The number of observations used in the various estimates
TABLE 5

Canadian and United States firms: cut-off level of volume of exports by destination

\begin{tabular}{clc}
\hline Model & \multicolumn{1}{c}{ Destination } & Cut-off level \\
\hline 1 & Country of origin of firm's majority capital $^{\text {a }}$ & $15 \%$ \\
2 & FTAA $^{\mathrm{a}}$ countries & $33 \%$ \\
3 & NAFTA $^{\text {b }}$ countries & $39 \%$ \\
4 & MERCOSUR $^{c}$ countries & $25 \%$ \\
\hline
\end{tabular}

Source: Prepared by the authors, on the basis of primary data from SECEX.

${ }^{a}$ Free Trade Area of the Americas.

${ }^{b}$ North American Free Trade Agreement.

c Southern Common Market.

TABLE 6

Probabilistic models for the destination of exports

\begin{tabular}{lcccc}
\hline Models $\rightarrow$ & \multicolumn{4}{c}{ Probit $^{\mathrm{a}}$} \\
\cline { 2 - 5 } Variables $\downarrow$ & $(1 \mathrm{a})$ & $(2 \mathrm{a})$ & $(3 \mathrm{a})$ & $(4 \mathrm{a})$ \\
\hline Constant & 0.6423 & 0.3021 & 0.7280 & 0.8716 \\
& $(0.448)$ & $(0.156)$ & $(0.165)$ & $(0.175)$ \\
Expsal $^{\mathrm{b}}$ & -0.0014 & -0.0012 & -0.0009 & -0.0003 \\
& $(0.001)$ & $(0.001)$ & $(.0005)$ & $(0.001)$ \\
Expat $^{\mathrm{c}}$ & 0.0000 & -0.0001 & 0.0002 & -0.0002 \\
& $(0.000)$ & $(0.000)$ & $(.0001)$ & $(0.000)$ \\
Expinc $^{\mathrm{d}}$ & 0.0997 & 0.0303 & -0.0219 & 0.0249 \\
& $(0.063)$ & $(0.003)$ & $(0.010)$ & $(0.003)$ \\
Salinc $^{\mathrm{e}}$ & 0.1998 & 0.0019 & 0.0009 & 0.0023 \\
& $(0.140)$ & $(0.000)$ & $(.0005)$ & $(0.000)$ \\
Patinc $^{\mathrm{f}}$ & 0.0213 & -0.0228 & -.00007 & -0.0626 \\
& $(0.160)$ & $(0.027)$ & $(.0001)$ & $(0.044)$ \\
\hline N & 43 & 182 & 182 & 182 \\
L.R. Chi $^{2}$ & 59.16 & 199.79 & 201.96 & 149.95
\end{tabular}

Source: Prepared by the authors, on the basis of primary data from SECEX.

${ }^{a}$ The numbers in brackets are standard errors of each coefficient.

${ }^{b}$ Growth rate of net earnings, 1995-2000.

${ }^{\text {c }}$ Proportion of total exports to net worth in 2000.

${ }^{d}$ Growth rate of exports by firm, 1995-2000.

${ }^{\mathrm{e}}$ Growth rate of net income by firm, 1995-2000.

${ }^{\mathrm{f}}$ Growth rate of net worth by firm, 1995-2000.

differed depending on the characteristics of the models applied and the data bank.

Models ( 2 a), (3 a) and (4 a) were based on 182 observations, or all those available which contained the following variables: firm's exports by country of destination in 1995 and 2000, firm's net income in 1995 and 2000 and firm's net worth in the same years.

Model ( 1 a) used only 43 observations, since 139 of the 182 observations used in models ( 2 a), $(3$ a) and 
(4 a) had to be excluded because they represented Brazilian firms, and it made no sense to take into account their exports to their country of origin. Moreover, as all the models used different variables or rates of variation between 1995 and 2000, it was impossible to make an isolated estimate for 1995 .

Table 6 reveals the same pattern in all the models. In general, a positive correlation was observed in all cases between the volume exported, the growth of net earnings and the growth of exports. It can also be seen that the ratio of total exports to net earnings and that of total exports to net worth are negatively correlated with the probability of exporting to the country of origin of the capital or to a regional trade bloc.

(1 a) Dependent variable destination 1 has a value of 1 if the ratio of each firm's exports to the country of origin of its capital exceeds $15 \%$ of the total; otherwise it has a value of 0 .

( 2 a) Dependent variable destination 2 has a value of 1 if the ratio of each firm's exports to the FTAA countries exceeds $33 \%$ of the total; otherwise it has a value of 0 .

(3 a) Dependent variable destination 3 has a value of 1 if the ratio of each firm's exports to the MERCOSUR countries exceeds $25 \%$ of the total; otherwise it has a value of 0 .

(4 a) Dependent variable destination $\mathbf{4}$ has a value of 1 if the ratio of each firm's exports to the NAFTA countries exceeds $39 \%$ of the total; otherwise it has a value of 0 .

Although the estimated coefficients had a low absolute value, the positive coefficients associated with the variables expinc and salinc suggest that firms which increased their sales and exports between 1995 and 2000 channelled their trade towards the countries of origin of their capital, and to the FTAA, MERCOSUR and NAFTA, in proportions greater than those of reference.

On the basis of the constant firms in our sample, we tried to estimate similar equations for firms with parent companies in Europe and Asia. Although the econometric findings are not solid, a crude analysis of these firms' export and import data suggests that the behaviour of Canadian and United States firms is not
TABLE 7

Brazil: destination of exports and imports by origin of capital, 1995 and 2000

\begin{tabular}{|c|c|c|c|}
\hline Country & $\begin{array}{l}\text { Percentage } \\
\text { of exports } \\
\text { to country } \\
\text { of origin }\end{array}$ & $\begin{array}{l}\text { Percentage } \\
\text { of exports } \\
\text { to continent } \\
\text { of origin }\end{array}$ & $\begin{array}{l}\text { Number } \\
\text { of firms }\end{array}$ \\
\hline Germany & 14.40 & 16.02 & 43 \\
\hline France & 4.60 & 26.70 & 23 \\
\hline Italy & 16.31 & 22.65 & 16 \\
\hline United Kingdom & 1.63 & 24.12 & 13 \\
\hline Total Europe & & 21.15 & 95 \\
\hline Japan & 19.59 & 19.59 & 22 \\
\hline Republic of Korea & 38.72 & 38.72 & 5 \\
\hline Total East Asia & & 24.27 & 27 \\
\hline United States & 20.66 & 23.73 & 82 \\
\hline Country & $\begin{array}{l}\text { Percentage } \\
\text { of imports } \\
\text { from country } \\
\text { of origin }\end{array}$ & $\begin{array}{c}\text { Percentage } \\
\text { of imports } \\
\text { from continent } \\
\text { of origin }\end{array}$ & $\begin{array}{l}\text { Number } \\
\text { of firms }\end{array}$ \\
\hline Germany & 38.7 & 44.5 & 27 \\
\hline France & 12.8 & 34.4 & 10 \\
\hline Italy & 23.7 & 34.9 & 8 \\
\hline United Kingdom & 6.1 & 27.8 & 7 \\
\hline Netherlands & 13.7 & 34.0 & 5 \\
\hline Switzerland & 24.2 & 26.2 & 3 \\
\hline Sweden & 10.7 & 29.9 & 3 \\
\hline Total Europe & & 36.0 & 63 \\
\hline Japan & 58.1 & 59.4 & 18 \\
\hline Republic of Korea & 52.9 & 61.5 & 2 \\
\hline Total Asia & 43.0 & 52.2 & 20 \\
\hline United States & & 55.4 & 50 \\
\hline
\end{tabular}

Source: Prepared by the authors, on the basis of primary data from SECEX.

abnormal. Table 7 , for example, shows that the country of origin of capital is still the preferred destination of the foreign trade of European and Asian firms operating in Brazil.

This supports our hypothesis that an analysis of economic agents may reveal certain sectoral trade consequences which differ from those derived from estimates of trade creation and diversion based on the structure of import barriers. 


\section{V}

\section{Conclusions}

The findings of this study indicate that export firms under foreign control maintain strong links with their parent companies. Firms registering an increase in their sales and exports between 1995 and 2000 channelled their activities preferentially to the countries of origin of their capital and to the FTAA, NAFTA and MERCOSUR countries.

In addition, we found that the greater the weight of foreign trade in relation to net earnings, the greater the probability that the firm will send a growing proportion of its exports to the country of origin of its capital. The same effect was noted when we investigated the impact of the growth of net earnings and total exports on exports to the country of origin of the capital.

It can thus be held, for example, that for firms whose capital primarily originates in the United States or Canada, the more their total sales and exports grow and the higher the ratio of their exports to their net earnings, the greater proportion they tend to export to the United States or Canada, depending on the case.

An analysis of the geographical origin of imports by United States and Canadian firms reveals that the relative weight of imports from the United States is double that of exports, and that these imports are primarily by firms in the sectors of motor vehicles and parts, chemicals and petrochemicals and household appliances, for which there is confirmation (in the literature on industrialized countries) concerning the incidence of intra-firm trade.

Such confirmation enhances the importance of analysing the potential impact of FTAA; subsidiaries of United States and Canadian firms operating in Brazil have a reasonably diversified structure for their exports, but they depend on the United States for almost 40\% of their imports, since their sales in that market are subject to the marketing structure of their parent companies.

We believe that this set of findings supports the main argument of this paper, namely, that certain intrafirm transactions -which the literature indicates are more highly concentrated in the sectors requiring skilled labour- could influence the estimates of the effects associated with trade preference agreements, by generating a different sectoral distribution of these effects than that obtained by estimating the amount of trade creation and diversion derived from the structure of import barriers.

As an illustration, Carvalho and Parente (1999) estimated the effects of FTAA on Brazilian exports and imports, on the basis of a partial equilibrium model which simulates the effects of the elimination of import tariffs. Their findings indicate an increase of $6.5 \%$ in Brazil's total exports and $20.6 \%$ in its total imports.

In comparison with the findings obtained in the present study, Carvalho and Parente estimated that, in the case of exports, the impact on chemicals, machinery, electrical equipment and transport equipment would be less significant than the mean, and this was also true of imports in the chemical industry. The indicators presented in our paper suggest, instead, that if the intra-firm effects -which are more intense precisely in segments of these industries- had been taken into account, it is very probable that the findings would have been different from those obtained on the sole basis of an analysis of the structure of trade barriers.

In a more general sense, this set of findings, though still preliminary, seems to confirm the result of research carried out in other countries, including the United States. Lipsey (1995), for example, notes the existence of trade networks between multinational corporations whose purpose is to improve their share of the export market, given that United States transnationals tend to export a greater share of their products to countries where their parent companies have a greater concentration of capital, and a lesser proportion to those in which they have no affiliates.

We stress that the findings presented here are merely illustrative of the importance of incorporating economic agents into studies of the impact of regional integration processes, and they are intended to encourage further studies of this matter.

BEHAVIOUR OF BRAZILIAN EXPORT FIRMS: IMPLICATIONS FOR THE FREE TRADE AREA

OF THE AMERICAS - RENATO BAUMANN AND FRANCISCO GALRÃO CARNEIRO 


\section{Bibliography}

Baldwin, R. (1989): Factor Market Barriers are Trade Barriers: Gains from Trade in 1992, NBER working paper, No. 2656, Cambridge, Massachusetts, National Bureau of Economic Research (NBER).

Baumann, R. (1995): An appraisal of intra-firm exports from Brazil, 1980-1990, The Developing Economies, vol. 33, No. 1, March.

Bonturi, M. and K. Fukasaku (1993): Globalisation and intra-firm trade: An empirical note, OECD Economic Studies, No. 20, París, Organization for Economic Co-operation and Development (OECD).

Carvalho, A. and A. Parente (1999): Impactos comerciais da área de livre comércio das Américas, Texto para discussão No. 635, Rio de Janeiro, Institute of Applied Economic Research (IPEA).

Federal Internal Revenue Secretariat (2002): O Comércio do Brasil com os Países da ALCA no Período de 1997 a 2000, www.receita.fazenda.gov.br/EstTributarios/ ComercioExterior/ Alca97a2000/default.htm

Helpman, E. and P. Krugman (1985): Market Structure and Foreign Trade: Increasing Returns, Imperfect Competition, and the International Economy, Cambridge, Massachusetts, MIT Press.

Krugman, P. (1986): Strategic Trade Policy and the New International Economics, Cambridge, Massachusetts, MIT Press.
Lipsey, R.E. (1995): Trade and Production Networks of U.S. MNCs and Exports by their Asian Affiliates, NBER working paper, No. 5255, Cambridge, Massachusetts, NBER.

Markusen, J.R. and A.J. Venables (1995): Multinational Firms and The New Trade Theory, NBER working paper, No. 5036, Cambridge, Massachusetts, NBER.

Markusen, J.R. and K.E. Maskus (1999): Multinational Firms: Reconciling Theory and Evidence, NBER working paper, No. 7163, Cambridge, Massachusetts, NBER.

OECD (Organization for Economic Co-operation and Development) (1996): Globalisation of Industry: Overview and Sector Reports, París.

Posner, M.V. (1961): International trade and technical change, Oxford Economic Papers, vol. 13, No. 3, London, Oxford University Press.

Takeuchi, K. (1990): Does Japanese Direct Foreign Investment Promote Japanese Imports from Developing Countries?, Paper, No. 458, Washington, D.C., World Bank, Country Economics Department.

Vernon, R. (1966): International investment and international trade in the product cycle, Quarterly Journal of Economics, vol. 80, Cambridge, Massachusetts, MIT Press.

Viner, J. (1950): The Customs Union Issue, New York, Carnegie Endowment for International Peace. 